Jurnal Health Sains: p-ISSN: 2723-4339 e-ISSN: 2548-1398

Vol. 2, No. 4, April 2021

\title{
FAKTOR-FAKTOR YANG BERHUBUNGAN DENGAN PERILAKU MEROKOK DI DALAM RUMAH PADA PETANI SAWAH DI KABUPATEN DELI SERDANG
}

\author{
Toman Devita Sari Siburian, Ida Yustina dan Juanita \\ Universitas Sumatera Utara, Medan, Indonesia \\ Email: tomandevita@gmail.com, idayust@yahoo.com dan joean_ita@yahoo.com
}

\begin{abstract}
ARTIKEL INFO
ABSTRACT

Tanggal diterima: 5 April 2021

One of the government's efforts to increase public health

Tanggal revisi: 15 April 2021

Tanggal yang disetujui: 25

April 2021

standard is by organizing Healthy Indonesia Program with family approach. The indicator is that no one of the family

Keywords:

smoking inside the houses;

knowledge members smoke. Smoking inside a house in Deli Serdang Regency is one of the public health problems. The result of the preliminary survey in 30 families who were wet rice field farmers in Deli Serdang Regency showed that 87\% of them smoked inside the their houses. The objective of the research was to analyze the relation of predisposing factors (knowledge, attitude) and reinforcing factors (the role of health care providers and wives' support) with smoking behavior inside the house of wet rice field farmers. The research used survey method with cross sectional design. The samples were 106 wet rice field farmers, taken by using simple random sampling technique. The data were gathered by using questionnaires and analyzed by using univariate analysis and bivariate analysis with chi square test. The result of the research showed that there was the relation of knowledge, attitude, the role of health care providers, and wives' support with the behavior of smoking inside the houses of wet rice field farmers. It is recommended that the Health Agency of Deli Serdang Regency make a policy of no smoking area houses and create special corners for smokers. The health care providers at the puskesmas should do health promotion to increase people's knowledge and attitude of wet rice field farmers and empower their wives in preventing their husbands from smoking inside their houses; they have to smoke outside their houses.
\end{abstract}

\begin{tabular}{l} 
ABSTRAK \\
Salah satu upaya pemerintah untuk meningkatkan \\
derajat kesehatan masyarakat adalah melalui \\
penyelenggaraan Program Indonesia Sehat dengan \\
pendekatan keluarga. Indikatornya adalah anggota keluarga \\
tidak ada yang merokok. Merokok di dalam rumah masih \\
merupakan salah satu masalah kesehatan masyarakat di \\
Kabupaten Deli Serdang. Hasil survei pendahuluan yang \\
dilakukan 30 kepala keluarga yang bekerja sebagai petani \\
\hline \\
Devita Sari, et. al. (2021) Faktor-Faktor Yang Berhubungan Dengan Perilaku \\
am Rumah Pada Petani Sawah Di Kabupaten Deli Serdang. Jurnal Health Sains 2(4). \\
althsains.co.id/index.php/jhs/article/view/144
\end{tabular}


sawah di Kabupaten Deli Serdang menunjukkan sebanyak 87 persen masih merokok di dalam rumah. Tujuan penelitian ini untuk menganalisis hubungan faktor predisposisi (pengetahuan, sikap) dan faktor pendorong (peran tenaga kesehatan dan dukungan istri) dengan perilaku merokok di dalam rumah pada petani sawah. Jenis penelitian adalah survei dengan pendekatan cross sectional. Jumlah sampel sebanyak 106 kepala keluarga yang bekerja sebagai petani sawah dengan pengambilan sampel menggunakan sample random sampling. Pengumpulan data diperoleh melalui kuesioner. Analisis data dilakukan dengan menggunakan univariat dan bivariat dengan uji chisquare. Hasil penelitian menunjukkan bahwa terdapat hubungan pengetahuan, sikap, peran tenaga kesehatan dan dukungan istri dengan perilaku merokok di dalam rumah pada petani sawah. Disarankan kepada Dinas Kesehatan Kabupaten Deli Serdang membuat kebijakan rumah bebas asap rokok dan membuat pojok merokok di tempat-tempat tertentu. Kepada tenaga kesehatan di puskesmas agar melakukan promosi kesehatan untuk meningkatkan pengetahuan dan sikap petani sawah, memberdayakan istri

Kata Kunci:

merokok di dalam rumah; pengetahuan dalam mencegah tindakan merokok di dalam rumah. Kepada istri diharapkan mengingatkan suaminya yang masih merokok di dalam rumah untuk merokok di luar rumah.

\section{Pendahuluan}

Penyakit Tidak Menular (PTM) merupakan salah satu masalah kesehatan global dimana setiap tahun kejadiannya meningkat. PTM menyebabkan 71 persen kematian secara global. Salah satu penyebab PTM ialah merokok dan terpapar asap rokok. Setiap tahun, sekitar 8 juta orang mengalami kematian akibat penggunaan tembakau. Tembakau juga bisa menyebabkan kematian bagi yang bukan perokok. Asap tembakau memiliki kontribusi pada penyakit kanker, jantung, dan lainnya, menyebabkan 1,2 juta kematian tambahan setiap tahunnya (Organization, 2019).

Berdasarkan Riskesdas tahun 2013 dan 2018 adanya peningkatan prevalensi PTM misalnya jantung, kanker dan stroke. Masalah kesehatan yang ada saat ini karena perilaku hidup tidak sehat. Hal ini dapat dicegah dengan memprioritaskan upaya preventif dan promotif untuk meningkatkan kemandirian

Jurnal Health Sains, Vol 2, No 4, April 2021 keluarga dan masyarakat supaya berperilaku hidup bersih dan sehat (PHBS).

Program Indonesia Sehat dengan Pendekatan Keluarga dirumuskan dua belas indikator utama status kesehatan dalam sebuah keluarga, salah satu indikatornya ialah tidak ada anggota keluarga yang merokok (Permenkes RI Nomor 39 Tahun 2016). Data Riskesdas pada tahun 2018 menjelaskan prevalensi merokok lingkup nasional yaitu 24,3 persen. Prevalensi merokok berdasarkan jenis kelamin sebesar 47,3 persen pada lakilaki dan 1,2 persen pada perempuan.

Mengutip laporan GYTS Indonesia tahun 2014 terdapat 61,4 juta pengguna tembakau saat ini dan sebesar $57,3 \%$ orang terpapar asap rokok di dalam rumah (Organization, 2019). Anak yang terpapar asap rokok akan meningkatkan risiko pneumonia, asma, bronkitis, infeksi telinga tengah, dan gangguan pertumbuhan paruparu. Gangguan kesehatan secara dini mengakibatkan gangguan kesehatan pada saat 
dewasa. Ketika dewasa yang tidak perokok bila terpapar maka meningkatkan bahaya berbagai jenis kanker (Kemenkes, 2011).

Penggunaan tembakau juga menaikan kesenjangan pada kesehatan dan ekonomi, di mana yang paling terdampak adalah kelompok masyarakat berpendapatan rendah. Masyarakat miskin menanggung beban paling besar akibat penyakit dan kematian akibat penggunaan tembakau dikarenakan oleh kurangnya sumber daya untuk perawatan kesehatan jika kepala keluarga sakit dan mengalami kematian prematur maka akan berdampak pada seluruh keluarga, terutama anak-anak.

Tercatat 55,07 persen rumah tangga yang mengimplementasikan PHBS di Sumatera Utara. Kabupaten Deli Serdang menempati posisi 19 terendah dari 33 kabupaten atau kota yang ada di Sumatera Utara (Sumut, 2018). Menurut data sekunder persentase rumah tangga ber-PHBS di Kabupaten Deli Serdang pada tahun 2018 berdasarkan rumah tangga yang dipantau dari 305.111 rumah tangga terdapat 69 persen rumah tangga sudah mengimplementasikan PHBS. Indikator PHBS terendah yaitu tidak merokok di dalam rumah 21 persen (Profil Kesehatan Kabupaten Deli Serdang, 2019).

Berdasarkan survei pendahuluan yang dilakukan terhadap 30 kepala keluarga yang bekerja sebagai petani sawah di Kabupaten Deli Serdang terdapat 26 kepala rumah tangga (87 persen) masih merokok di dalam rumah. Mereka mengatakan sejak remaja sudah merokok dan mampu menghabiskan 1 bungkus rokok (8-12 batang) per hari dan mereka membeli rokok per batang yang mereka beli di warung sekitar rumah mereka. Pendapatan mereka paling sedikitnya $\mathrm{Rp}$ 1.800.000 rupiah per bulan, pengeluaran ratarata per bulan untuk kebutuhan makan seharihari sebesar $\mathrm{Rp} 1.050 .000$ dan pengeluaran tembakau sebesar Rp 360.000. Masih rendahnya pendapatan yang diperoleh petani sawah ditambah biaya untuk mencukupi keperluan hidup kesehariannya makin tinggi dan umumnya petani sawah memiliki kebiasaan merokok setiap hari. Hal ini menimbulkan resiko terhadap petani sawah jika mengalami sakit akan menimbulkan berupa beban ekonomi yang semakin berat bagi keluarga.

Pengetahuan petani sawah akan bahaya merokok di dalam rumah masih kurang, mereka menganggap merokok di dalam rumah hanya merugikan diri sendiri padahal asap yang dihasilkan oleh rokok dapat dihirup oleh anggota keluarga yang dapat membahayakan kesehatan perokok dan keluarganya. Hal tersebut sesuai dengan hasil penelitian yang dilaksanakan (Trisnowati \& Daduk, 2017) dengan judul penelitian Hubungan Pengetahuan dan Sikap terhadap PHBS di Rumah Tangga dengan Perilaku Merokok Dalam Rumah Kepala Rumah Tangga di Dusun Karangnongko Yogyakarta menunjukkan ada hubungan pengetahuan dan sikap terhadap PHBS rumah tangga dengan perilaku merokok dalam rumah dengan $\mathrm{p}$ value masing-masing 0,000 dan 0,004 ( $\mathrm{p}<$ $0,005)$.

Mereka belum berhenti melakukan tindakan merokok disebabkan tidak ada kemauan sedikit pun untuk menghentikan tindakan merokok. Merokok dikalangan petani sawah dilakukan pada saat santai setelah seharian bekerja di sawah hal itu dimaksudkan untuk melepas lelah. Mereka merokok hingga saat ini karena sudah ketergantungan dengan rokok. Masih kurangnya dukungan istri kepada perokok dikarenakan merokok sudah menjadi kebiasaan sehingga menggangap merokok adalah hal yang biasa. Berdasarkan penelitian (Sutikno, 2018) dengan judul penelitian Dukungan Istri dengan Perilaku Merokok Suami di Desa Ngujung Kecamatan Maospati Kabupaten Magetan menunjukkan ada hubungan dukungan istri dengan perilaku merokok suami dengan uji Rank Spearman didapatkan nilai $\mathrm{p}=0,013(\mathrm{p}<0,05)$. 
Masih tingginya perilaku merokok di dalam rumah berdasarkan data PHBS di Kabupaten Deli Serdang diduga ada kaitannya dengan peran tenaga kesehatan kurang optimal. Hal ini sejalan dengan penelitian (Daroji dkk, 2011) dengan judul penelitian Peran Petugas Puskesmas dalam Promosi Kesehatan Berhenti Merokok pada Pasien dan Masyarakat menjelaskan bahwa peran staff puskesmas dalam mempromosikan menghentikan aktivitas merokok belum optimal karena kompetensi yang terbatas, kendala internal dan eksternal dan kepercayaan buruk terhadap kesuksesan.

Petani sawah yang masih merokok di dalam rumah menyebabkan petani sawah dan keluarganya akan berisiko jangka panjang mengalami masalahkesehatan yang disebabkan asap rokok yang akan berimplikasi pada terjadinya angka kesakitan dan kematian. Berdasarkan hasil wawancara belum ada aturan mengenai larangan merokok di dalam rumah.

Penelitian ini bertujuan untuk menganalisis hubungan faktor predisposisi (pengetahuan, sikap) dan faktor pendorong (peran tenaga kesehatan dan dukungan istri) dengan perilaku merokok di dalam rumah pada petani sawah di Kabupaten Deli Serdang.

\section{Metode Penelitian}

Jenis penelitian yang digunakan adalah survei dengan pendekatan cross sectional. Penelitian ini akan dilakukan di Kabupaten Deli Serdang, karena indikator PHBS tidak merokok di dalam rumah masih kategori buruk yakni 21 persen (Profil Kesehatan Kabupaten Deli Serdang tahun 2019). Waktu penelitian dilaksanakan mulai dari bulan Februari 2020 hingga Desember 2020.

Populasi dalam penelitian ini adalah kepala keluarga yang bekerja sebagai petani sawah di kecamatan yang terpilih. Besar sampel dapat ditentukan dengan mengunakan rumus besar sampel (Lemeshow et al., 1987) didapatkan sampel sebesar 106 responden. Besar sampel untuk setiap kecamatan, ditentukan dengan teknik sampel alokasi proporsional random sampling. Teknik untuk pengambilan sampel dilakukan dengan teknik simple random sampling.

Kriteria inklusi dalam penelitian ini adalah 1) Kepala keluarga yang bekerja sebagai petani sawah, 2) Kepala keluarga perokok aktif 3) Bersedia menjadi responden penelitian. Kriteria eksklusi yakni menghilangkan atau mengeluarkan subjek penelitian yang tidak memenuhi kriteria inklusi.

Variabel independen dalam penelitian ini faktor predisposisi (pengetahuan dan sikap), faktor pendorong (peran tenaga kesehatan dan dukungan istri). Variabel dependen dalam penelitian ini yaitu perilaku merokok di dalam rumah. Pengumpulan data diperoleh dari responden (sampel) secara langsung melalui wawancara dengan responden, berpedoman pada kuesioner yang telah disusun. Analisis data dilakukan dengan menggunakan univariat dan bivariat dengan uji chi-square.

\section{Hasil dan Pembahasan}

\section{A. Hasil Penelitian}

1. Analisis Univariat

a. Karakteristik Responden

Berdasarkan penelitian ini umur responden didominasi umur 20-40 tahun sebanyak 69 orang $(65,1 \%)$. Pendidikan responden yang paling dominan adalah SMP sebanyak 49 orang $(46,2 \%)$. Pendapatan responden didominasi pendapatan rendah (Rp. < 2.900.000) sebanyak 91 orang $(85,8 \%)$. Jumlah anak responden yang paling dominan adalah > 2 anak sebanyak 90 orang $(84,9 \%)$. Usia pertama kali merokok didominasi usia 15-19 tahun sebanyak 69 orang $(65,1 \%)$. 
Berdasarkan penelitian ini jumlah batang rokok per hari responden yang paling dominan 11-20 batang sebanyak 49 orang $(46,2 \%)$. Pengeluaran untuk membeli rokok sebulan didominasi pengeluaran rokok tinggi (Rp. $\geq 157.000)$ sebanyak 97 orang $(91,5 \%)$.

\section{Tabel 1}

\section{Distribusi Frekuensi Karakteristik}

\begin{tabular}{|c|c|c|}
\hline Karakteristik Responden & $\mathrm{n}$ & $\%$ \\
\hline \multicolumn{3}{|l|}{ Umur } \\
\hline Dewasa muda (20-40 tahun) & 69 & 65,1 \\
\hline Dewasa akhir (diatas 40 tahun) & 37 & 34,9 \\
\hline \multicolumn{3}{|l|}{ Pendidikan } \\
\hline SD & 25 & 23,6 \\
\hline SMP & 49 & 46,2 \\
\hline SMA & 32 & 30,2 \\
\hline \multicolumn{3}{|l|}{ Pendapatan } \\
\hline Rendah (Rp. $<2.900 .000)$ & 91 & 85,8 \\
\hline Tinggi (Rp. $\geq 2.900 .000)$ & 15 & 14,2 \\
\hline \multicolumn{3}{|l|}{ Jumlah anak } \\
\hline$\leq 2$ anak & 16 & 15,1 \\
\hline$>2$ anak & 90 & 84,9 \\
\hline \multicolumn{3}{|l|}{ Usia pertama kali merokok } \\
\hline $5-9$ tahun & 0 & 0 \\
\hline 10-14 tahun & 15 & 14,2 \\
\hline 15-19 tahun & 69 & 65,1 \\
\hline 20-24 tahun & 21 & 19,8 \\
\hline $25-29$ tahun & 1 & 0,9 \\
\hline$>30$ tahun & 0 & 0 \\
\hline \multicolumn{3}{|l|}{ Jumlah batang rokok per hari } \\
\hline Perokok ringan (1-10 batang) & 27 & 25,5 \\
\hline Perokok sedang (11-20 batang) & 49 & 46,2 \\
\hline Perokok berat (> 20 batang) & 30 & 28,3 \\
\hline \multicolumn{3}{|l|}{ Pengeluaran membeli rokok sebulan } \\
\hline $\begin{array}{l}\text { Pengeluaran rokok rendah } \\
(\operatorname{Rp} 0-\operatorname{Rp} 50.000)\end{array}$ & 0 & 0 \\
\hline $\begin{array}{l}\text { Pengeluaran rokok sedang } \\
(\mathrm{Rp} 51.000-\mathrm{Rp} 156.000)\end{array}$ & 9 & 8,5 \\
\hline $\begin{array}{l}\text { Pengeluaran rokok tinggi } \\
(\mathrm{Rp} \geq 157.000)\end{array}$ & 97 & 91,5 \\
\hline
\end{tabular}

b. Distribusi Frekuensi Responden Berdasarkan Kategori Pengetahuan, Sikap, Peran Tenaga Kesehatan dan Dukungan Istri terhadap Perilaku Merokok di Dalam Rumah

Secara keseluruhan pengetahuan petani sawah didominasi dengan kategori cukup sebanyak $58(54,7 \%)$ responden, sikap petani sawah didominasi dengan kategori cukup 57 (53,8\%) responden, peran tenaga kesehatan didominasi dengan kategori kurang baik sebanyak $66(62,3 \%)$ responden dan dukungan istri didominasi dengan kategori dukungan istri mendukung sebanyak $58(54,7 \%)$ responden.

Tabel 2

Distribusi Frekuensi Responden Berdasarkan Kategori Pengetahuan, Sikap, Peran Tenaga Kesehatan dan Dukungan Istri terhadap Perilaku Merokok di Dalam Rumah

\begin{tabular}{lcc}
\hline Kategori Pengetahuan & $\mathrm{n}$ & $\%$ \\
\hline Baik & 22 & 20,8 \\
\hline Cukup & 58 & 54,7 \\
\hline Kurang & 26 & 24,5 \\
\hline Kategori Sikap & $\mathrm{n}$ & $\%$ \\
\hline Baik & 33 & 31,1 \\
\hline Cukup & 57 & 53,8 \\
\hline Kurang & 16 & 15,1 \\
\hline Kategori Peran Tenaga & $\mathrm{n}$ & $\%$ \\
Kesehatan & & \\
\hline Baik & 40 & 37,7 \\
\hline Kurang Baik & 66 & 62,3 \\
\hline Kategori Dukungan Istri & $\mathrm{n}$ & $\%$ \\
\hline Mendukung & 58 & 54,7 \\
\hline Kurang Mendukung & 48 & 45,3 \\
\hline
\end{tabular}

2. Analisis Bivariat

Analisis bivariat dilakukan untuk melihat hubungan antara variabel independen (pengetahuan, sikap, peran tenaga kesehatan, dan dukungan istri) dengan variabel dependen (perilaku merokok di dalam rumah) dengan menggunakan uji chi-square dengan tingkat kepercayaan $95 \%$.

Berdasarkan tabel hasil analisis bivariat diperoleh bahwa faktor pengetahuan, sikap, peran tenaga kesehatan dan dukungan istri berhubungan dengan perilaku merokok di dalam rumah yang ditentukan dengan nilai $\mathrm{p}<0,05$.

Rincian distribusi frekuensi hubungan pengetahuan, sikap, peran tenaga kesehatan dan dukungan istri petani sawah dengan perilaku merokok di dalam rumah di Kabupaten Deli Serdang dapat dilihat pada Tabel 3 berikut: 
Tabel 3

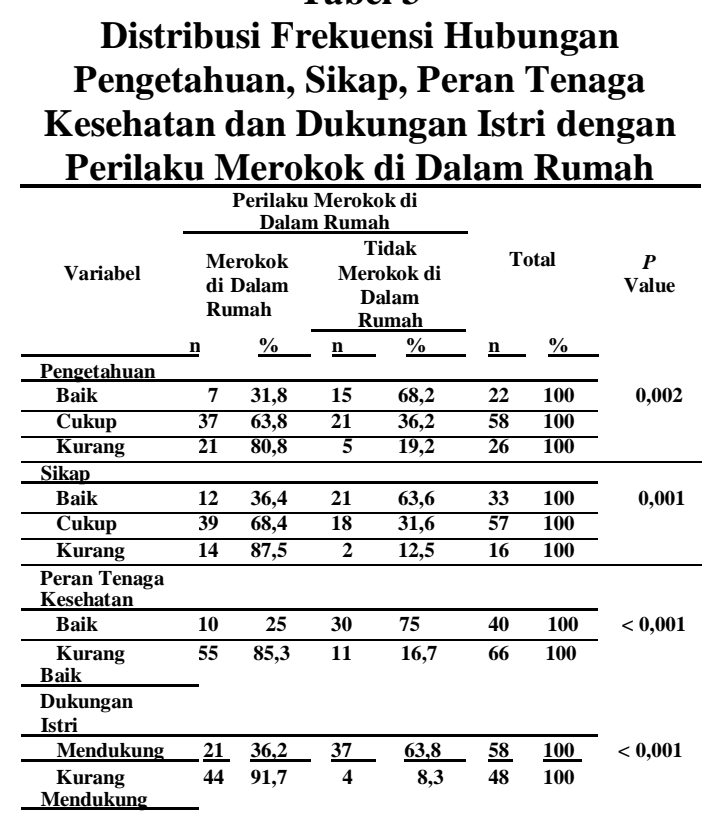

\section{B. Pembahasan}

1. Perilaku merokok di dalam rumah

Perilaku merokok di dalam rumah pada petani sawah di Kabupaen Deli Serdang menunjukkan hasil terbanyak pada kategori merokok di dalam rumah. Hal ini bertentangan dengan salah satu Indikator Program Indonesia Sehat dengan pendekatan keluarga yaitu anggota keluarga tidak ada yang merokok. Berdasarkan hasil wawancara dengan petani sawah menyebutkan bahwa paling banyak petani sawah merokok di dalam rumah karena sudah menjadi suatu kebiasaan, menghilangkan kebosanan, menenangkan pikiran, mengurangi rasa lelah dan malas keluar rumah. Petani sawah mayoritas pulang kerja jam 5 sore, setelah mereka mandi, ibadah, dan makan malam mereka berperilaku merokok di dalam rumah dan hal tersebut sudah biasa.

Petani sawah merokok di dalam rumah meskipun di dalam rumah tersebut ada istri, anak, bahkan ada orang tua. Ini tentu saja, asap dan risiko rokok tersebut mengakibatkan keluarga petani sawah yang ada di dalam rumah menjadi perokok pasif (secondhand smoke) dan ada yang menjadi thirdhand smoke yang sebenarnya dapat dicegah dengan mengkondisikan rumah sebagai rumah tanpa asap rokok dengan tidak merokok di dalam rumah.

2. Hubungan pengetahuan dengan perilaku merokok di dalam rumah pada petani sawah

Hubungan pengetahuan dengan perilaku merokok di dalam rumah pada petani sawah dengan nilai $\mathrm{p}=0,002$ $(\mathrm{p}<0,05)$. Hasil ini sejalan dengan penelitian (Prabandari dkk, 2018) dengan judul penelitian Faktor yang Berkontribusi pada Komitmen Rumah Bebas Asap Rokok? Studi Baseline Peer Health di Nusa Tenggara Barat menunjukkan bahwa variabel pengetahuan mengenai dampak paparan asap rokok berhubungan dengan komitmen rumah bebas asap rokok.

Berdasarkan penelitian ini ada sebanyak 26 (24,5\%) responden kepala rumah tangga yang bekerja sebagai petani sawah mempunyai pengetahuan perilaku merokok di dalam rumah dengan kategori kurang, ini disebabkan kurangnya mendapatkan informasi PHBS sehingga pengetahuan kepala rumah tangga tentang PHBS terutama merokok di dalam rumah masih kurang.

Hasil penelitian bahwa petani sawah merokok di dalam rumah pada saat anggota keluarga tidak ada di rumah kurang berbahaya, hal ini menjadi poin karena petani sawah memiliki pengetahuan yang kurang tentang efek asap rokok yang ditinggalkan pasca merokok. Racun dari asap rokok yang ditinggalkan perokok di dalam ruangan akan 
bertahan selama 4-6 jam. Partikel rokok dapat menempel pada sofa, gorden bahkan baju yang dipakai. Hal ini sejalan dengan penelitian (Muin dkk, 2018) bahwasanya masih banyak masyarakat utamanya laki-laki yang merokok di dalam rumah karena mereka tidak mengetahui bahaya merokok di dalam rumah, mereka hanya mengetahui bahaya merokok pada dirinya sendiri tetapi mereka tidak mengetahui siapa-siapa saja yang dapat dibahayakan kondisi kesehatannya bila merokok di dalam rumah.

Penelitian systematic literature riview yang dilakukan oleh (Stevenson dkk, 2017) mengenai membangun rumah bebas asap rokok pada penduduk asli di Australia, Kanada dan Amerika Serikat menyatakan pengetahuan menjadi pemicu motivasi orang tua untuk melindungi anaknya dari SHS dengan menerapkan rumah bebas asap rokok ditambah dengan komunikasi yang jelas tentang peraturan rumah bebas asap rokok akan lebih berhasil menerapkan rumah bebas asap rokok.

3. Hubungan sikap dengan perilaku merokok di dalam rumah pada petani sawah

Secara statistik menunjukkan ada hubungan sikap dengan perilaku merokok di dalam rumah pada petani sawah dengan nilai $\mathrm{p}=0,001 \quad(\mathrm{p}<0,05)$. Gambaran sikap kurang dilihat dari pernyataan setuju bahwa merokok di dalam rumah akan membuat pikiran tenang setelah bekerja seharian dan pernyataan merokok di dalam rumah tidak masalah jika tidak ada anggota keluarga lainnya. Sikap baik dilihat dari kesediaan merokok di luar rumah walaupun tidak ada orang di dalam rumah. Sikap yang baik terhadap perilaku merokok di dalam rumah dikarenakan petani sawah mempunyai keyakinan bahwa lingkungan yang bebas dari asap rokok mempunyai dampak yang positif bagi kesehatan.

Setiap keluarga harus dibekali dengan pengetahuan tentang rumah tanpa asap rokok, karena rokok merupakan salah satu yang membuat lingkungan sekitar kita menjadi tidak sehat, karena asap yang dihasilkannya mengandung banyak zat yang berbahaya yang dapat mengakibatkan tercemarnya lingkungan serta menganggu kesehatan penikmatnya maupun orang disekitarnya.

Hasil penelitian ini sejalan dengan penelitian (Puspitasari, 2016) dengan judul penelitian Hubungan Pengetahuan tentang Rokok dengan Sikap dan Perilaku Merokok di Dalam Rumah di Kota Yogyakarta menunjukkan ada hubungan antara sikap merokok di dalam rumah dengan perilaku merokok di dalam rumah. Berdasarkan penelitian (Iwan, 2013) dengan judul penelitian Faktor-faktor yang Berhubungan dengan Tindakan Merokok Kepala Keluarga di Dalam Rumah di Wilayah Kerja Puskesmas Kuranji Tahun 2013 menunjukkan ada hubungan sikap dengan tindakan merokok kepala keluarga di dalam rumah.

Seseorang yang merasa rokok berbahaya bagi kesehatannya cenderung untuk bersikap tegas melindungi diri dari paparan asap rokok. Sementara itu kepala keluarga yang bersikap baik namun masih berperilaku merokok cenderung dipengaruhi faktor tobacco dependency (ketergantungan rokok). Hal itu menjadi alasan utama mengapa kepala keluarga sulit untuk menghilangkan kebiasaan merokok. 
4. Hubungan peran tenaga kesehatan dengan perilaku merokok di dalam rumah pada petani sawah

Secara statistik menunjukkan ada hubungan peran tenaga kesehatan dengan perilaku merokok di dalam rumah pada petani sawah dengan nilai $\mathrm{p}=<0,001 \quad(\mathrm{p}<0,05) . \quad$ Kurangnya kesadaran dan sikap kurang baik masyarakat tentang bahaya rokok bagi diri dan orang-orang di sekelilingnya menyebabkan kurangnya kemampuan masyarakat untuk mengubah perilakunya dan menciptakan lingkungan yang sehat. Untuk itu perlu dilakukan upaya pencegahan. Salah satu upaya pencegahan yang dapat dilakukan adalah kegiatan penyuluhan untuk memberikan pengetahuan kepada masyarakat sehingga meningkatkan kesadaran mereka tentang bahaya rokok dan asap rokok bagi kesehatan.

Hasil penelitian ini sesuai dengan teori Lawrence Green dimana dalam teori disebutkan bahwa tenaga kesehatan merupakan salah satu faktor pendorong. Dukungan tenaga kesehatan dapat menunjang perilaku kepala keluarga dalam penerapan perilaku tidak merokok di dalam rumah. Hal ini dikarenakan kepercayaan warga menjadi lebih meningkat apabila suatu program kesehatan ditangani dan dipantau secara langsung oleh pihak puskesmas.

Penelitian ini menunjukkan bahwa petani sawah merokok di dalam rumah selain kurangnya pengetahuan akan dampak bahaya merokok di dalam rumah dan juga dikarenakan belum adanya kebijakan larangan merokok di dalam rumah. Kabupaten Deli Serdang merupakan salah satu kabupaten yang sudah memiliki peraturan tentang KTR yakni Peraturan Bupati Deli Serdang No 310 Tahun 2017. Berdasarkan peraturan bupati tersebut KTR meliputi fasilitas pelayanan kesehatan, tempat proses belajar mengajar, tempat anak bermain, tempat ibadah, angkutan umum, fasilitas olahraga, tempat kerja, dan tempat umum atau tempat lain yang ditetapkan namun di dalam peraturan bupati tersebut tidak diatur tentang larangan merokok di dalam rumah.

Penelitian yang dilakukan oleh (Zheng dkk, 2014) mengenai rumah bebas asap rokok dan rumah yang terpapar asap rokok di Shanghai, Cina menyatakan dari 355 responden bukan perokok sebanyak $127 \quad(35,8 \%)$ responden melaporkan terpapar SHS dalam 7 hari terakhir. Responden yang tinggal dengan perokok, tanpa ada larangan merokok di dalam rumah dan memiliki anak dibawah 18 tahun lebih mungkin terpapar SHS di dalam rumah. Langkah efektif untuk melindungi dari paparan SHS di dalam rumah adalah mempromosikan rumah bebas asap rokok, menerapkan kebijakan larangan merokok di dalam rumah.

Strategi dalam menggurangi keterpaparan asap rokok di dalam rumah bagi perokok pasif juga dapat dilakukan dengan membuat pojok merokok di tempat-tempat tertentu. Perokok yang belum bisa menghentikan kebiasaan merokok agar merokok di pojok merokok yang telah disediakan.

5. Hubungan dukungan istri dengan perilaku merokok di dalam rumah pada petani sawah

Secara statistik menunjukkan ada hubungan dukungan istri dengan perilaku merokok di dalam rumah pada petani sawah dengan nilai $\mathrm{p}=<0,001$ $(\mathrm{p}<0,05)$. Rokok sudah menjadi kebutuhan hidup petani sawah yang tidak bisa ditinggalkan dalam 
kehidupan sehari-hari. Kurangnya dukungan istri petani sawah kepada petani sawah karena menganggap merokok di dalam rumah adalah hal yang biasa. Hal tersebut disebabkan kurangnya komunikasi, informasi dan edukasi (KIE) yang diberikan oleh tenaga kesehatan kepada keluarga terutama istri terkait bahaya kesehatan apabila merokok di dalam rumah. Perlunya KIE akan bahaya asap rokok kepada keluarga dapat mengarahkan pemahaman yang lebih baik tentang asap rokok serta penerapan aturan bebas asap rokok di dalam rumah.

Penelitian ini umumnya menjelaskan bahwa dukungan istri yang mendukung dengan memberikan informasi bahaya merokok di dalam rumah, mengingatkan untuk berhenti merokok di dalam rumah, menasihati tidak merokok di dalam rumah serta memberikan pujian apabila berhenti merokok di dalam rumah.

Salah satu faktor yang memengaruhi keberhentian merokok adalah pengaruh pasangan, hal sederhana yang bisa dilakukan agar bisa mencegah terpaparnya asap rokok disesuaikan dengan kebiasaan merokok anggota keluarga di dalam rumah, dengan memberdayakan ibu rumah tangga sebagai rambu-rambu yang dipatuhi oleh anggota keluarga yang diharapkan kelak dapat menertibkan perokok dan mencegah agar asap rokok yang dihasilkan tidak terhirup oleh orang lain yang bukan perokok di dalam rumah (Hayati \& Sulami, 2018).

Istri dapat memberikan informasi mengenai bahaya merokok dengan cara memberikan nasihat kepada anggota keluarga mengenai bahaya merokok. Istri juga dapat menghimbau perokok aktif untuk menggunakan uang konsumsi rokok dialihkan sebagai dana untuk pemenuhan kebutuhan rumah tangga seperti membeli makanan bergizi, pemenuhan kebutuhan sekolah anak dan lain-lain yang lebih bermanfaat. Berdasarkan penelitian penelitian (Ediana \& Sari, 2021) menunjukkan ada hubungan peran keluarga dengan kebiasaan merokok di dalam rumah.

Hasil penelitian ini diharapkan dapat memberikan manfaat bagi pihakpihak yang membutuhkan antara lain: 1) Manfaat teoritis yaitu sebagai masukan dan tambahan referensi tentang faktor-faktor yang berhubungan dengan perilaku merokok di dalam rumah. 2) Manfaat aplikatif bagi Puskesmas yaitu sebagai bahan untuk menyusun strategi program dalam meningkatkan kinerja puskesmas tentang PHBS terutama tidak merokok di dalam rumah. 3) Manfaat aplikatif bagi masyarakat. yaitu sebagai sumber pengetahuan untuk mengubah perilaku hidup sehat dengan tidak merokok di dalam rumah.

\section{Kesimpulan}

Ada hubungan faktor pengetahuan, sikap, peran tenaga kesehatan dan dukungan istri dengan perilaku merokok di dalam rumah pada petani sawah di Kabupaten Deli Serdang Tahun 2020. Disarankan kepada Dinas Kesehatan Kabupaten Deli Serdang membuat kebijakan rumah bebas asap rokok dan membuat pojok merokok di tempattempat tertentu. Kepada tenaga kesehatan di puskesmas agar melakukan promosi kesehatan untuk meningkatkan pengetahuan dan sikap petani sawah, memberdayakan istri dalam mencegah tindakan merokok di dalam rumah. Kepada istri diharapkan mengingatkan suaminya yang masih merokok di dalam rumah untuk merokok di luar rumah. 


\section{BIBLIOGRAFI}

Daroji, M., Prabandari, Y. S., Paramastri, I. (2011). Peran Petugas Puskesmas Dalam Berhenti Merokok Pada Pasien Dan Masyarakat. Berita Kedokteran Masyarakat, 27(2), 83-93. Google Scholar

Ediana, D., \& Sari, N. (2021). Faktor-Faktor Yang Berhubungan Dengan Kebiasaan Merokok Dalam Rumah. Jurnal Endurance: Kajian Ilmiah Problema Kesehatan, 6(1), 150-161. Google Scholar

Hayati, Z., Sulami, N. (2018). Peran Ibu Rumah Tangga Dalam Pencegahan Perilaku Merokok Keluarga Di Dalam Rumah. Jurnal Kebidanan Dan Kesehatan, 3(2). Google Scholar

Iwan, A (2013). Faktor-faktor Yang Berhubungan Dengan Tindakan Merokok Kepala Keluarga Di Dalam Rumah Di Wilayah Kerja Puskesmas Kuranji Tahun 2013. Google Scholar

Kemenkes. (2011). Pedoman Pengembangan Kawasan Tanpa Rokok. Google Scholar

Lemeshow, S., Teres, D., Avrunin, J. S., \& Pastides, H. (1987). A Comparison Of Methods To Predict Mortality Of Intensive Care Unit Patients. Critical Care Medicine, 15(8), 715-722. Google Scholar

Muin, H., Lisnawati, Arsyad, M. (2018). Peran Puskesmas Dalam Program Perilaku Hidup Bersih dan Sehat Tatanan Rumah Tangga di Kelurahan Padaidi Kecamatan Mattiro Bulu Kabupaten Pinrang. Jurnal Ilmiah Manusia dan Kesehatan, 1(1), 42-52. Google Scholar

Organization, W. H. (2019). Global Status Report On Alcohol And Health 2018. World Health Organization. Google Scholar
Prabandari, Y. S., Padmawati, R. S., Cranshaw, E., Mellen, R. C. (2018). Faktor Yang Berkontribusi Pada Komitmen Rumah Bebas Asap Rokok? Studi Baseline Peer Health Di Nusa Tenggara Barat Indonesia. Proceeding 5th Indonesian Conference on Tobacco or Health 2018, 23-30. Google Scholar

Puspitasari, R. D. (2016). Hubungan Pengetahuan Tentang Rokok Dengan Sikap Dan Perilaku Merokok Di Dalam Rumah Di Kota Yogyakarta. Universitas Gadjah Mada. Google Scholar

Stevenson, L., Campbell, S., Bohanna, I., Gould, G. S., Robertson, J., Clough, A. R. (2017). Establishing Smoke-Free Homes In The Indigenous Populations Of Australia, New Zealand, Canada and The United States: A Systematic Literature Review. International Journal Of Environmental Research And Public Health, 14 (11). Google Scholar

Sumut, D. (2018). Profil Kesehatan Kabupaten Sumatera Utara. Sumatera Utara. Diakses, 11. Google Scholar

Sutikno, A. (2018). Dukungan Istri Dengan Perilaku Merokok Suami Di Desa Ngujung Kecamatan Maospati Kabupaten Magetan. STIKes Insan Cendikia Jombang. Google Scholar

Trisnowati, H., \& Daduk, S. S. (2017). Hubungan Pengetahuan Dan Sikap Terhadap PHBS Di Rumah Tangga Dengan Perilaku Merokok Dalam Rumah Kepala Rumah Tangga Di Dusun Karangnongko Yogyakarta. Medika Respati: Jurnal Ilmiah Kesehatan, 12(4), 1-11. Google Scholar

Zheng, P., Berg, C . J., Kegler, M. C., Fu, W.,Wang, J., Zhou, X., Liu, D., Fu, H. (2014). Smoke-Free Homes And Home Exposure To Secondhand Smoke In Shanghai, Cina. Int. J. Environ. Res. Public Health, 11, 12015-12028. Google 
Toman Devita Sari Siburian, Ida Yustina dan Juanita

Scholar

Copyright holder :

Toman Devita Sari Siburian, Ida Yustina dan Juanita (2021)

First publication right :

Jurnal Health Sains

This article is licensed under:

(c) (†) (?) 